\title{
Coaching. Fundamente teoretice şi direcţii aplicative
}

\author{
Lucia Raţiu ${ }^{1,2}$, Adriana Băban \\ Universitatea Babeş-Bolyai Cluj-Napoca
}

\begin{abstract}
Coaching is now a common practice for human development and change and, especially an instrument for organizational development. Although widely used, coaching does not have a precise scientific framework, as it is a field in the theoretical construction phase. This article provides a critical review of studies on coaching in order to summarize the theoretical models which support research, to identify the results in this field, and to present the mechanisms for change and efficiency in coaching. The results reported are still insufficient to conclude on the relationship between certain factors and the benefits of coaching. Finally future research directions are presented to clarify the components and the purpose of the coaching process.
\end{abstract}

Keywords: coaching, executive coaching, change mechanisms in coaching, coaching effectiveness

\section{Résumé}

Le coaching est aujourd'hui une pratique courante au changement et le développement humain et, surtout, un outil de développement organisationnel. Bien que largement utilisé, le coaching ne bénéficie pas d'une classification scientifique précise, parce que c'est un domaine en phase de construction théorique. L'article propose une analyse critique des études de coaching, afin de résumer les modèles théoriques qui soutiennent les recherches, d'identifier les résultats dans ce domaine et de présenter les mécanismes de changement et de rendre le coaching plus efficace. Les résultats rapportés dans la littérature sont encore insuffisantes pour déterminer la relation entre certains facteurs et les avantages du coaching. Enfin les pistes de recherche sont évaluées à apporter des clarifications concernant les éléments et le but du processus de coaching.

Mots-clés: coaching, coaching pour la gestion des personnes, mécanismes de changement dans coaching, efficacité de la coaching

\section{Rezumat}

Coaching-ul este în prezent o practică frecventă pentru schimbarea şi dezvoltarea umană şi, cu precădere, un instrument de dezvoltare organizaţională. Deşi mult utilizat, coaching-ul nu beneficiază de o încadrare ştiinţifică precisă, fiind un domeniu în fază de construcţie teoretică. Articolul oferă o analiză critică a studiilor de coaching, cu scopul de sumariza modele teoretice ce susţin cercetările, de a identifica rezultatele în domeniu şi de a prezenta mecanismele de schimbare şi de eficientizare a coaching-ului. Rezultatele raportate în literatură sunt încă insuficiente pentru a concluziona asupra relaţiei dintre anumiţi factori şi beneficiile coaching-ului. În final, sunt punctate direcţii viitoare de cercetare care să aducă clarificări legate de componentele şi finalitatea procesului de coaching.

Cuvinte cheie: coaching, coaching-ul pentru persoane cu funcţii de conducere, mecanisme de schimbare în coaching, eficienţa coaching-ului

\footnotetext{
1 Autoarea doreşte să mulţumească pentru suportul financiar din programul co-finanţat de PROGRAMUL OPERATIIONAL SECTORIAL PENTRU DEZVOLTAREA RESURSELOR UMANE 2007 - 2013, Contract POSDRU 6/1.5/S/4 - „STUDII DOCTORALE, FACTOR MAJOR DE DEZVOLTARE AL CERCETĂRILOR SOCIOECONOMICE ŞI UMANISTE".

${ }^{2}$ Adresa de corespondenţă: luciaratiu@psychology.ro
} 


\section{Introducere}

Coaching-ul este în prezent o practică frecventă pentru schimbarea şi dezvoltarea umană (Cox, Bachkirova \& Clutterbuk, 2009; Grant, 2008). Termenul de coaching nu are o istorie prea îndelungată deşi, ca practică organizaţională, a fost întâlnit cu mult înainte de anii '90 sub denumiri de consiliere sau consultanţă (Judge \& Cowell, 1997). Acest termen desemnează o relaţie de suport şi facilitare între un practician al coaching-ului (coach) şi un client, în vederea atingerii scopurilor personale şi profesionale ale acestuia din urmă (Wilkins, 2000). Noutatea termenului şi a practicii de coaching face dificilă existenţa unui consens privind definirea şi dimensiunile conceptuale.

Coaching-ul implică o relaţie de tip unu-la-unu, însă nu se reduce la abordarea individuală. Coaching-ul de grup este o intervenţie asupra echipei pentru dezvoltarea comportamentelor de leadership, pentru managementul stresului, pentru luarea deciziilor în grup şi pentru îmbunătăţirea muncii în echipă (Cox et al., 2009; Ennis, Goodman, Otto \& Ster, 2008). În coaching-ul individual, dar şi în cel de grup, practicianul are rolul de îndrumător care facilitează dezvoltarea aptitudinilor şi comportamentului unei persoane sau a unei echipe pentru obţinerea performanţei dorite. Elementele definitorii ale coaching-ului sunt învăţarea, facilitarea învăţării, optimizarea funcţionării şi / sau depăşirea problemelor unui client, prin valorificarea resurselor personale, rezultatul intervenţiei fiind îmbunătăţirea stilului de viaţă şi creşterea eficienţei profesionale.
Aria de aplicaţii ale coaching-ului se întinde de la dezvoltarea unui set specific de abilităţi pentru funcţionarea personală eficientă, la dezvoltarea carierei. Organizaţiile investesc din ce în ce mai mult în coaching, ca instrument adecvat pentru sporirea implicării angajaţilor, a stării de bine şi a performanţei profesionale. Astfel, a dobândit un rol din ce în ce mai important printre opţiunile de intervenţii în scop de dezvoltare în organizaţii (Grant, 2007; Underhill, McAnally \& Koriath, 2007).

Coaching-ul, atât ca domeniu ştiinţific, cât şi aplicativ, se află în stadiu de dezvoltare (Kleinberg, 2003). Practica de coaching, în special a formelor din domeniul business, a evoluat într-un ritm mai alert decât cercetarea. Literatura academică proprie coaching-ului nu deţine încă o teorie solidă, iar cercetarea empirică este încă destul de restrânsă (Bennett, 2006; Latham, 2007).

Studiile şi cercetările pe coaching sau publicat într-un număr semnificativ mai mare începând cu 1995, aşa cum ilustrează datele din figura 1. Numărul de articole şi studii publicate în reviste academice reprezintă $15 \%$ din lucrările de coaching. Chiar şi în literatura academică, studiile empirice au o pondere mai mică - 18\% - faţă de abordările teoretice (Grant, 2006). Evoluţia studiilor indică un sens ascendent ca număr, dar articolele publicate sunt, în mare parte, descrieri din practică şi mai puţin cercetări în domeniu care să satisfacă, din punct de vedere metodologic, standardele academice (Grant \& Zackon, 2004).

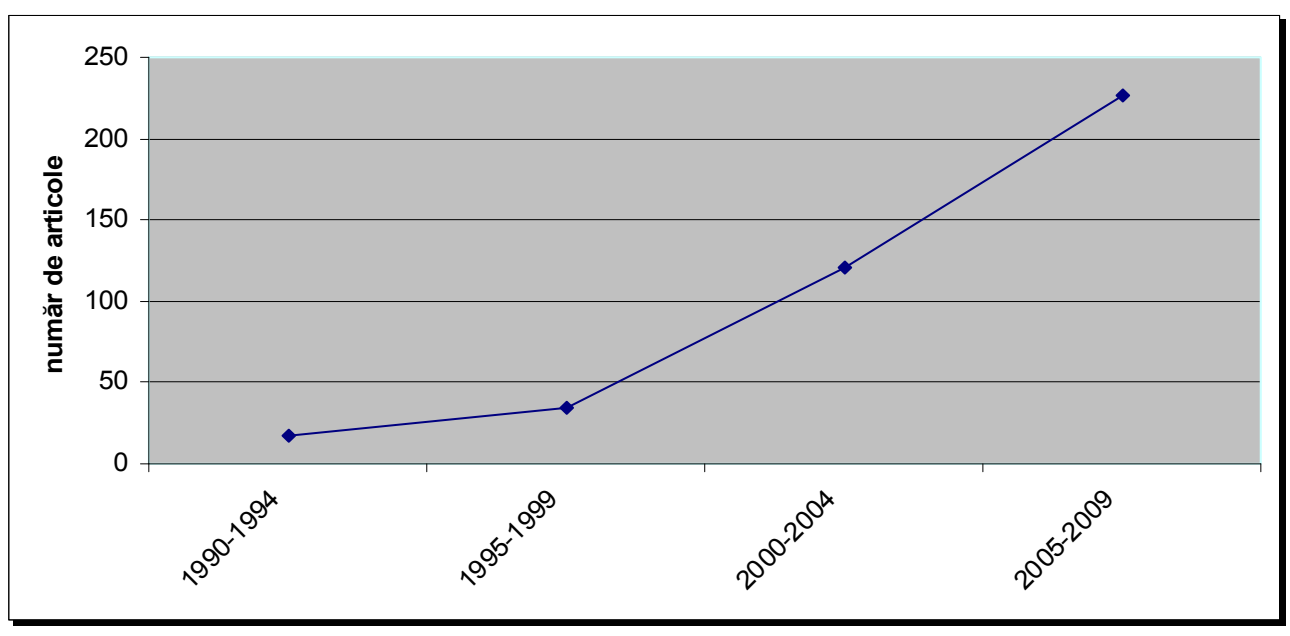

Figura 1. Evoluţia numărului de lucrări ştiinţifice pe coaching 


\section{Coaching-ul ca relaţie de dezvoltare}

Coaching-ul se integrează în categoria relaţiilor în scop de învăţare şi dezvoltare, alături de consiliere, mentorat, psihoterapie, consultanţă sau training. În general, o relaţie de acest gen se stabileşte între un specialist şi o persoană care îşi propune să atingă un scop de dezvoltare personal sau profesional şi este motivată să înveţe şi să se dezvolte (Higgins \& Kram, 2001).

Relaţiile în scop de dezvoltare prezintă o mare diversitate dată de: a. durata relaţiei (lungă sau scurtă); b. tipul relaţiei (instrumentală sau nu); c. stilul specialistului (directiv sau nu); d. obiectul învăţării (învăţare centrată pe sine sau pe sarcină); e. efectul asupra reţelei în care este implicată persoana care învaţă. (Rock \& Garavan, 2006).
Similarităţile dintre coaching şi alte relaţii în scop de dezvoltare sunt date, în principal, de caracteristicile relaţiei: o relaţie de sprijin care oferă clientului oportunitatea de a reflecta, învăţa şi progresa; derulată, de obicei, unu-la-unu şi faţă-în-faţă, bazată pe încredere şi confidenţialitate între un profesionist şi un client. Diferenţa majoră este dată de poziţia specialistului faţă de client; în coaching se stabileşte un parteneriat între practician şi client, pe când în mentorat, consultanţă sau psihoterapie, specialistul se situează pe poziţie de expert care oferă răspunsuri şi soluţii la probleme. Alte similarităţi şi deosebiri sunt date de tehnicile utilizate, pregătirea specialistului care realizează intervenţia, abordarea teoretică ce o fundamentează, durata acesteia. Tabelul 1 prezintă sintetic compararea coaching-ului $\mathrm{cu}$ alte relaţii în scop de dezvoltare.

Tabelul 1. Comparaţia coaching-ului cu alte relaţii în scop de dezvoltare (adaptat după Jarvis, 2004)

\begin{tabular}{|c|c|c|c|c|c|}
\hline Relaţia & Coaching & Mentorat & Consultanţă & Consiliere & Psihoterapie \\
\hline Clientul & $\begin{array}{l}\text { Persoane cu funcţii de } \\
\text { conducere, alte persoane } \\
\text { care vizează dezvoltarea } \\
\text { personală sau } \\
\text { profesională }\end{array}$ & $\begin{array}{l}\text { Angajaţi la } \\
\text { diferite niveluri }\end{array}$ & $\begin{array}{l}\text { Persoane cu } \\
\text { putere de decizie } \\
\text { şi cu influenţă } \\
\text { asupra întregii } \\
\text { organizaţii }\end{array}$ & $\begin{array}{l}\text { Persoane în } \\
\text { situaţii } \\
\text { problematice }\end{array}$ & $\begin{array}{l}\text { Persoane cu } \\
\text { tulburări } \\
\text { psihopatologice }\end{array}$ \\
\hline Profesionistul & $\begin{array}{l}\text { Practician al coaching-ului } \\
\text { specializat în funcţie de } \\
\text { tipurile de coaching; } \\
\text { frecvent, extern } \\
\text { organizaţiei }\end{array}$ & $\begin{array}{l}\text { Mentor, de } \\
\text { regulă intern } \\
\text { organizaţiei }\end{array}$ & $\begin{array}{l}\text { Consultant } \\
\text { organizaţional, } \\
\text { frecvent extern } \\
\text { organizaţiei }\end{array}$ & $\begin{array}{l}\text { Consilierul } \\
\text { psihologic }\end{array}$ & Psihoterapeutul \\
\hline $\begin{array}{l}\text { Cunoştinţe } \\
\text { Expert }\end{array}$ & $\begin{array}{l}\text { Dezvoltare şi schimbare } \\
\text { umană, cunoştinţe din } \\
\text { domeniul afacerilor şi } \\
\text { organizaţiilor în cazul } \\
\text { coaching-ului pentru } \\
\text { afaceri }\end{array}$ & $\begin{array}{l}\text { Specifice } \\
\text { domeniului } \\
\text { profesional } \\
\text { al clientului }\end{array}$ & $\begin{array}{l}\text { Management, } \\
\text { dezvoltare şi } \\
\text { intervenţie } \\
\text { organizaţională, } \\
\text { resurse umane }\end{array}$ & $\begin{array}{l}\text { Din domeniul } \\
\text { psihologiei }\end{array}$ & $\begin{array}{l}\text { Legate de } \\
\text { psihopatologie }\end{array}$ \\
\hline $\begin{array}{l}\text { Ţinta principală } \\
\text { a intervenţiei }\end{array}$ & $\begin{array}{l}\text { Problemele curente ale } \\
\text { individului şi orientare } \\
\text { spre viitor }\end{array}$ & $\begin{array}{l}\text { Individul şi } \\
\text { orientare spre } \\
\text { viitor }\end{array}$ & $\begin{array}{l}\text { Organizaţia şi } \\
\text { prezentul }\end{array}$ & $\begin{array}{l}\text { Individul şi } \\
\text { prezentul }\end{array}$ & $\begin{array}{l}\text { Individul şi } \\
\text { problemele din } \\
\text { trecut }\end{array}$ \\
\hline Rezultatul & $\begin{array}{l}\text { De la stare de bine, } \\
\text { dezvoltare personală la } \\
\text { performanţe profesionale } \\
\text { ca rezultate proximale şi } \\
\text { beneficii la nivelul } \\
\text { organizaţiei ca rezultat } \\
\text { distal }\end{array}$ & $\begin{array}{l}\text { De la socializare } \\
\text { organizaţională } \\
\text { la noi abilităţi } \\
\text { de management }\end{array}$ & $\begin{array}{l}\text { Soluţii pentru } \\
\text { problemele } \\
\text { organizaţionale, } \\
\text { dezvoltare } \\
\text { organizaţională }\end{array}$ & $\begin{array}{l}\text { Soluţii pentru } \\
\text { problemele } \\
\text { emoţionale, de } \\
\text { relaţionare } \\
\text { interpersonală, } \\
\text { conflict }\end{array}$ & $\begin{array}{l}\text { Rezolvarea } \\
\text { problemelor } \\
\text { psihopatologice } \\
\text { şi a traumelor } \\
\text { psihologice }\end{array}$ \\
\hline Durata & Scurtă sau medie & De regulă lungă & De regulă medie & $\begin{array}{l}\text { De regulă } \\
\text { scurtă }\end{array}$ & De regulă lungă \\
\hline
\end{tabular}


Aspectele redate în tabelul 1 impun o serie de precizări: (i) coaching-ul, îndeosebi coachingul pentru persoane cu funcţii de conducere, se apropie cel mai mult de mentorat, iar dimensiunile lor comune îi conduc pe unii autori să utilizeze termenii interşanjabil (Young \& Perrewe, 2000); (ii) delimitarea între coaching şi consultanţă se aplică, mai degrabă, în cazul coaching-ului pentru afaceri şi coaching-ului pentru persoane cu funcţii de conducere. În acelaşi timp, coaching-ul poate fi un instrument sau o formă de consultanţă (Kampa \& White, 2002) sau poate fi o metodă a intervenţiei organizaţionale (Stern, 2004); (iii) atât coaching-ul, cât şi consilierea se concentrează pe nevoia de dezvoltare, dar coaching-ul are ca şi scop primar dezvoltarea de abilităţi eficiente pentru atingerea scopurilor personale şi profesionale, în timp ce consilierea ţinteşte, mai ales, dezvoltarea emoţională, socială şi spirituală (Filipczac, 1998); (iv) în domeniul muncii-organizaţional, termenul de coaching îl substituie pe cel de psihoterapie pentru a evita conotaţiile negative - asociate cu patologia - ale acestuia din urmă (David, 2007); (v) deşi coaching-ul are puncte comune şi cu activitatea de training, diferenţa este dată de faptul că practicianul coaching-ului nu îşi propune de la început un model prestabilit sau un rezultat anume, ci acestea sunt formulate pe parcursul intervenţiei împreună cu clientul. Trainingul vizează transmiterea de cunoştinţe declarative şi/sau procedurale, mizând pe faptul că participanţii le vor aplica în practică, dar nu garantează realizarea efectivă a modificării (David, 2007). În schimb, coaching-ul este "croit" individual pe persoană şi pe o problemă sau un aspect actual, opus abordării de grup din cadrul seminariilor şi programelor de training. În ultima decadă, opţiunea pentru coaching în organizaţii, mai ales în SUA şi Marea Britanie, a crescut simţitor, ca alternativă la tradiţionalul training pentru dezvoltarea abilităţilor de conducere (Lawton-Smith \& Cox, 2007; Feldman \& Lankau, 2005).

Eforturile de a realiza delimitări precise între coaching şi alte relaţii în scopul dezvoltării au condus la conturarea unor teme centrale care se pot constitui în alte criterii de diferenţiere. O primă temă este caracteristica relaţiei între practicianul coaching-ului şi client - o relaţie de colaborare şi egalitate, nu una de tip autoritar. A doua temă centrală se referă la abordarea problemelor, accentul fiind pus pe soluţii şi pe procesul de atingere a scopurilor mai degrabă, decât pe analiza problemelor. Stabilirea în comun a scopurilor este o altă temă relevantă pentru coaching. $\mathrm{O}$ a patra temă conţine asumpţia că cei care sunt implicaţi într-un proces de coaching sunt persoane fără probleme de sănătate mentală de intensitate clinică. Tema finală se referă la recunoaşterea faptului că specialiştii în coaching au expertiză în facilitarea învăţării, dar nu trebuie să deţină un nivel ridicat de expertiză în domeniul de specializare al clientului (Brennan \& Prior, 2005).

În concluzie, coaching-ul este un proces sistematic, orientat spre o învăţare continuă şi o dezvoltare personală a clientului şi se integrează prin aceste elemente în sfera relaţiilor de sprijin al dezvoltării. Aceste relaţii pornesc de la asumpţia că adulţii care învaţă sunt autonomi, au un fundament solid de experienţă de viaţă şi cunoştinţe pe care să le valorifice, au o propensiune pentru a se dezvolta. Caracteristicile enunţate pun în evidenţă apropierea coaching-ului de mentorat, consiliere, consultanţă, etc., dar, totodată, şi diferenţele specifice. Delimitarea terminologică este importantă în selecţia şi aplicarea procedurilor şi tehnicilor de intervenţie şi evaluare adecvate fiecărui tip de problemă şi client.

\section{Forme de coaching}

În prezent se practică diferite forme de coaching care prezintă similarităţi, dar şi multiple diferenţe în funcţie de unul sau mai multe criterii la care se raportează: tipul clienţilor, motivul recurgerii la coaching, forma relaţiei dintre practicianul coaching-ului şi client.

Cercetările raportează mai multe clasificări ale formelor de coaching. În funcţie de tipul clienţilor şi problemele acestora, se disting trei forme: 1 . coaching de viaţă, numit şi coaching personal; 2. coaching pentru persoane cu funcţii de conducere; şi 3 . coaching managerial (Sperry, 2004). Formele de coaching se diferenţiază şi în funcţie de criteriul finalităţii - de exemplu, 1. coaching de viaţă, 2. pentru carieră, 3. de dezvoltare, 4 . pentru performanţă, 5 de relaţionare etc. fără a fi organizate în categorii mai cuprinzătoare (Ennis et al., 2008). După forma relaţiei, se pot diferenţia două tipuri de coaching, şi anume: faţă-în-faţă şi virtual (electronic sau prin telefon). Oricare dintre tipurile de coaching identificate anterior pot să se desfăşoare sau nu faţă-în-faţă. Dacă la 
origine, coaching-ul implica o relaţie interpersonală directă, dată fiind dezvoltarea tehnologiei de comunicare, precum şi globalizarea, coaching-ul electronic şi prin telefon sunt forme din ce în ce mai utilizate.

Multitudinea etichetelor utilizate nu este corelată direct cu aceeaşi varietate a formelor de coaching, aceeaşi practică regăsindu-se sub denumiri diferite. Prin urmare, reţinem două categorii majore: coaching-ul personal şi coaching-ul pentru afaceri, diferenţiate pe baza tipului persoaneiclient şi a mediului de referinţă al intervenţiei (în organizaţie sau în afara ei). Orice alte etichete care se utilizează exprimă nuanţe ale problemei-ţintă din coaching, nu neapărat un cadru diferit de abordare.

Coaching-ul personal desemnează o relaţie profesională în care un practician specializat asistă clientul în a-şi proiecta viitorul mai degrabă, decât a depăşi probleme din trecut. Printr-o relaţie specifică pe termen mediu sau lung, practicianul coaching-ului îl ajută pe client să îşi stabilească şi să îşi clarifice scopurile pentru toate aspectele vieţii şi să găsească strategii pentru a le atinge (Stern, 2004; Williams \& Davis, 2002; Auerbach, 2001). Îndrumarea persoanelor în realizarea planurilor de viaţă conduce spre un viitor mai apropiat de cel dorit, la dezvoltarea carierei sau la o viaţă familială optimizată.

Coaching-ul personal este denumit şi coaching pentru viaţă sau coaching pentru succes. Tipuri ale coaching-ului personal sunt: coaching-ul relaţional, coaching coactiv, coaching-ul pentru dezvoltarea personală, pentru carieră, coaching-ul pentru sănătate, etc., particularizate în funcţie de scopul ţintă al clientului (Ennis et al., 2008; McKelley \& Rochlen, 2007; Irwing \& Morrow, 2005; Sperry, 2004). Unele dintre tipurile de coaching personal amintite sunt mai frecvent utilizate. De exemplu, coaching-ul pentru sănătate se extinde rapid, ca şi practică, şi se conturează ca o specializare pentru dezvoltarea şi stimularea adoptării de comportamente sanogene (Gale \& Lindner, 2007; Palmer, Tubbs \& Whybrow, 2003).

În toate tipurile enumerate, practicienii coaching-ului personal lucrează cu diferite categorii de persoane - adolescenţi, studenţi, profesionişti în diverse domenii, persoane care se află în tranziţie în carieră, adulţi în general. Problemele cărora se adresează intervenţia pot fi intra şi interpersonale, având ca ţintă o mai bună funcţionare în general şi starea de bine. Coaching-ul personal, prin conţinutul său, devine o abordare bazată pe valorile personale, şi de asemenea, o abordare holistică a schimbării şi dezvoltării umane (Cox et al., 2009). Coaching-ul personal a evoluat rapid şi se îndreaptă spre conturarea unor date care să demonstreze eficienţa şi validitatea sa.

Coaching-ul pentru organizaţii sau pentru afaceri (business coaching) este un domeniu emergent, ce valorifică aspectele de vârf din psihologia organizaţională şi industrială, consultanţă în management, dezvoltare organizaţională, consultanţă în afaceri, şi contribuie la conturarea unei noi viziuni a funcţionării individului în organizaţie şi a organizaţiei în sine. Această formă de coaching se regăseşte şi sub denumiri de coaching de management, coaching pentru persoane cu funcţii de conducere, coaching pentru leadership. În practică, termenii sunt deseori superpozabili.

Coaching-ul pentru afaceri se adresează investitorilor, managerilor, directorilor, persoanelor cu funcţii de conducere de la toate nivelurile, etc. având ca scop principal producerea de rezultate favorabile atât pentru client, cât şi pentru companie (Fairley \& Stout, 2004). Aspectele vizate preponderent de coaching-ul de afaceri sunt dezvoltare, schimbare şi o eficienţă sporită a angajaţilor şi implicit a organizaţiei.

Unul dintre tipurile coaching-ului pentru afaceri este coaching-ul managerial sau de supervizare. Coaching-ul managerial desemnează „eforturi continue, de zi cu zi ale managerilor sau supervizorilor pentru a dezvolta performanţa angajaţilor şi a le valorifica potenţialul. Obiectivul este de a responsabiliza angajaţii pentru a asigura, în cel mai înalt grad, angajamentul lor şi aderarea la obiectivele organizaţionale" (Eitington, 1997, p. 280).

Între coaching-ul managerial şi cel pentru persoane cu funcţii de conducere există o relaţie circulară: persoanele cu funcţii de conducere care au fost antrenate într-un proces de coaching vor adopta şi aplica practici de coaching în relaţie cu subalternii lor (Sperry, 2004). Dintre toate tipurile de coaching pentru afaceri, coaching-ul pentru persoane cu functiii de conducere are cea mai mare vizibilitate atât în practică, cât şi în cercetare.

Coaching-ul personal şi cel de afaceri se pot desfăşura şi în mediul virtual, prin intermediul Internetului sau al telefonului. Evoluţia tehnologiei, în special comunicarea 
prin Internet, a facilitat nu numai accesul clienţilor la coaching şi la practicienii coaching-ului, dar şi includerea comunicării virtuale în procesul intervenţiei (Berry, 2006; Bennett, 2006; Sperry, 2004). Se preconizează ca pe viitor, coaching-ul virtual sau electronic să fie mult utilizat datorită globalizării şi rentabilităţii. Globalizarea determină o nouă dinamică a funcţionării organizaţiilor şi accesul la un context mai extins. Astfel, sesiunile de coaching pot avea loc şi în condiţiile în care practicianul coaching-ului şi clientul nu se găsesc în aceeaşi locaţie geografică. În plus, este mai avantajos din punct de vedere al costurilor. De regulă, anumite secvenţe ale coaching-ului virtual se desfăşoară cu necesitate faţă-înfaţă. Este vorba de prima sesiune în care se stabileşte relaţia practician-client, moment esenţial pentru reuşita procesului (Ennis et al., 2008; Sperry, 1993, 1996). Demersul de intervenţie în coaching-ul virtual urmează în prezent modelele preluate din coaching-ul faţă-în-faţă, iar măsurarea eficienţei, la nivel de client, vizează factori globali ca: atingerea scopului, starea de bine, modificări comportamentale, funcţionare mai eficientă. Coaching-ul virtual, din punct de vedere teoretic, este o direcţie mai puţin explorată, fiind necesare studii empirice care să fundamenteze eficienţa sa şi să ofere un cadru de orientare a interacţiunii virtuale dintre practician şi client.

Sumarizând, coaching-ul pentru persoane cu funcţii de conducere (EC executive coaching) este cea mai extinsă în practică şi mai studiată formă a coaching-ului, fapt pentru care secţiunea următoare va analiza în detaliu funcţiile, mecanismele şi efectele acestuia.

\section{Coaching-ul pentru persoane cu funcţii de conducere}

Popularitatea în creştere a EC este un răspuns la cerinţele prezentului pentru domeniul de afaceri (De Meuse, Dai \& Lee, 2009; Joo, 2005). Formarea de lideri performanţi şi dezvoltarea unor strategii optime de afaceri au devenit priorităţi şi o nouă sursă pentru profitul economic. Însă, pentru a introduce schimbări în timp real, persoanele cu funcţii de conducere au nevoie de sprijin. EC constituie un suport în acest sens şi oferă posibilitatea de a explora aspecte care, deseori în dinamismul prezentului, trec neobservate (Sherman \& Freas, 2004).

Cea mai acceptată şi frecvent citată definiţie a EC este cea formulată de Kilburg $(1996,2001)$ care conceptualizează EC ca o relaţie de facilitare stabilită între un client cu autoritate managerială şi responsabilitate în organizaţie şi un consultant; acesta utilizează o varietate de tehnici şi metode pentru a sprijini clientul în achiziţionarea unui set de strategii de optimizare. În acest sens, cei doi formulează în comun un set de scopuri legate de îmbunătăţirea performanţei profesionale, creşterea satisfacţiei personale şi, consecutiv, creşterea eficienţei organizaţiei în cadrul căreia se desfăşoară în mod formal coachingul. Această definiţie conţine aspecte comune şi altor definiţii, şi anume: a) conceptualizarea relaţiei de coaching ca relaţie de colaborare de tip unu-la-unu (Garman, Whiston, \& Zlatoper, 2000; Stern, 2004); b) obţinerea de date legate de performanţa clientului, comportamentul de muncă, personalitate, posibile probleme (Kampa-Kokesch \& Anderson, 2001); c) scopuri orientate de informaţii cantitative şi/sau calitative; d) furnizarea şi utilizarea feedbackului (Gregory, Levy \& Jeffers, 2008).

Un aspect esenţial pe care EC îl desemnează este relaţia triangulară între practicianul coaching-ului care realizează intervenţia, persoana cu funcţie de conducere care este direct implicată în proces şi organizaţia-client care plăteşte intervenţia de coaching (Sherman \& Freas, 2004). Astfel, EC vizează producerea de schimbări comportamentale la nivelul persoanei cu funcţie de conducere şi, în acelaşi timp, rezolvarea problemelor organizaţionale (Kutzhanova, Lyons \& Lichtenstein, 2009). EC poate aborda în paralel aspecte de carieră şi viaţă personală a persoanei cu funcţii de conducere, cum ar fi de exemplu, echilibrul muncă-viaţă. $O$ astfel de situaţie apropie abordarea EC de coaching-ul personal. Totuşi, există o linie de demarcaţie între EC şi alte forme de coaching. EC implică întotdeauna un parteneriat între persoana cu funcţii de conducere, practician al EC şi organizaţie. Un alt aspect diferenţiator are în vedere faptul că scopurile individuale din cadrul unui contract de coaching trebuie să se subordoneze obiectivelor organizaţionale strategice.

Complexitatea organizaţională şi a funcţionării indivizilor în organizaţie face dificilă o circumscriere exactă a domeniului EC. Însă, eforturile din cercetare sunt 
considerabile pentru a realiza o conturare a domeniului şi a elabora modele viabile de orientare a practicii.

\section{Funcţiile EC}

Iniţial, din punct de vedere „istoric”, EC s-a dezvoltat ca intervenţie de remediere, de optimizare a rezultatelor obţinute de persoanele cu funcţii de conducere, de conectare a eficienţei individuale cu performanţa organizaţională (McCauley \& Hezlett, 2001). În prezent, rolul practicianului s-a schimbat, trecând, în mare măsură, de la "expert" care oferă susţinere în rezolvarea problemelor la partener de reflecţie (Eggers \& Clark, 2000). De asemenea, EC poate oferi sprijin pentru angajaţii cu potenţial de avansare în carieră (McCauley \& Hezlett, 2002). Printre motivele majore pentru care este utilizat EC se numără dezvoltarea abilităţilor de conducere, îmbunătăţirea stilului managerial, rezolvarea problemelor de relaţionare, formarea de abilităţi de conducere şi management la persoanele prea orientate pe sarcină. Prin rezultatele pe care le ţintesc, practicienii EC re-aplică, în cadrul organizaţional, practici de consultanţă şi consiliere (Tobias, 1996). Astfel, funcţiile majore ale EC sunt: funcţia de remediere şi funcţia de dezvoltare (Joo, 2005).

Functia de remediere în coaching se impune când apar simptome ca: incapacitate de decizie, comunicare ineficientă, dificultăţi în concentrare, amânare. Prin remediere, se urmăreşte eliminarea acestor simptome şi atingerea unor standarde de performanţă în munca persoanelor cu funcţii de conducere (Hodgetts, 2002). Tinta EC în astfel de situaţii este de a corecta comportamentele disfuncţionale (Joo, 2005).

Funcţia de dezvoltare în coaching vizează sporirea capacităţii de a îndeplini sarcinile şi atingerea obiectivelor la locul de muncă. În acest caz, coaching-ul este orientat pe rezultate şi focalizat pe acţiune. Asumpţia de bază a funcţiei de dezvoltare este aceea că persoanele cu funcţii de conducere vor învăţa mai mult când urmăresc scopuri pe care le-au definit ele însele, decât scopuri definite de alţii.

Funcţiile EC evidenţiază perspectiva interdisciplinară, dar şi dificultatea de a trasa graniţe precise între coaching, psihoterapie, consiliere şi consultanţă.

\section{Fundamentarea teoretică a coaching-ului}

În general, studiile asupra coachingului sunt în mare parte teoretice, având scop de clarificare conceptuală, delimitare teoretică şi construire de modele; totodată, este subliniată nevoia unei înţelegeri mai profunde a procesului de coaching şi a factorilor care asigură succesul intervenţiei (Kilburg, 1996, 2004; Lowman, 2005).

Cercetarea legată de coaching, alături de maturizarea coaching-ului ca şi profesie, se află în faza embrionară (Bennett, 2006). Activitatea de coaching este desfăşurată şi de practicieni care nu au pregătire în psihologie, intervenţia acestora fiind de cele mai multe ori ateoretică şi bazată pe modele locale, particulare ale coaching-ului. Studiile publicate până în prezent nu au validat un model de competenţe în coaching; mai degrabă, se recurge la modele cu valoare euristică, inspirate din intervenţiile „înrudite”.

$\mathrm{Ca}$ şi alte tipuri de intervenţie din psihologia organizaţională, coaching-ul, în special cel pentru afaceri, a pornit de la adaptarea de teorii, concepte şi metode ale altor discipline ale psihologiei (Latham, 2007). Cele mai multe modele se axează pe coaching-ul pentru persoane cu funcţii de conducere, construit pe modele provenite din dezvoltarea organizaţională, educaţia adulţilor, training pentru management, psihologie industrială şi organizaţională, precum şi psihologie clinică (Kilburg, 1996). Studiile de EC au fost publicate în proporţii relativ egale în literatura psihologică şi de management, ceea ce indică o substanţială contribuţie atât a teoriilor psihologice, cât şi a celor organizaţionale (Kampa-Kokesch \& Anderson, 2001).

Teoriile, modelele şi abordările practicii, indiferent de forma de coaching, se axează pe două direcţii: abordări dintr-o perspectivă teoretică singulară şi abordări din perspective teoretice multiple, integrative (Banning, 1997; Diedrich, 1996; Kiel, Rimmer, Williams, \& Doyle, 1996; Nowack \& Wimer, 1997; Peterson, 1996; Saporito, 1996). Practicienii coaching-ului tind să fie eclectici în raport cu metodele pe care le utilizează, dar cu toate acestea, aderă preponderent la un model teoretic (Barner \& Higgins, 2007).

Abordările teoretice asumate de către practicieni pentru intervenţiile de coaching urmează, în linii mari, paradigmele majore din studiul personalităţii particularizate pe procesul de schimbare şi dezvoltare a individului (vezi 
tabelul 2). Pe baza acestor teorii sunt descrise patru modele care informează şi ghidează intervenţiile de coaching, construind legătura între teorie şi practică. Modele sunt implicite, nu se regăsesc întocmai în practică, dar pot fi recunoscute elementele dominante ale unuia sau altuia: (i) modelul clinic, (ii) modelul comportamental, (iii) modelul sistemic şi (iv) modelul social-constructivist (Barner \& Higgins, 2007). Fiecare dintre ele prezintă avantaje, dar niciunul nu deţine supremaţia. Modelul social-constructivist este probabil cel mai controversat pentru studiul EC. Asumpţia de bază este că semnificaţiile sunt construite prin interacţiunile sociale şi în cadrul simbolic în care indivizii interacţionează (Blumer, 1986).
Elementul central este limbajul cu rol nu doar pentru a descrie realitatea, ci şi de a o delimita şi interpreta (Ford, 1999). Într-un astfel de cadru, coaching-ul se desfăşoară ca interacţiune şi comunicare pentru a crea noi sensuri. De exemplu, definirea unui „lider eficient”, a „unei performanţe de vârf", „maximizarea potenţialului” variază în funcţie de modul în care aceste concepte au fost construite în diferite culturi organizaţionale. Consecutiv, intervenţia practicienilor EC se localizează la nivelul înţelegerii realităţilor organizaţionale, a rolurilor pe care actorii organizaţionali le deţin şi a modului cum interacţionează.

Tabelul 2. Abordări teoretice ale practicii de coaching (după Peltier, 2001)

\begin{tabular}{|c|c|c|c|}
\hline Paradigme & Elementul central & Elemente de intervenţie & Efecte urmărite \\
\hline Psihodinamică & $\begin{array}{l}\text { Gândurile inconştiente şi } \\
\text { stările psihologice interne }\end{array}$ & $\begin{array}{l}\text { Surmontarea distanţei între „ego” } \\
\text { ideal şi realitate; mecanisme } \\
\text { defensive; transfer; } \\
\text { contratransfer; dinamici familiale }\end{array}$ & $\begin{array}{l}\text { Nivelul de conştientizare a } \\
\text { gândurilor, emoţiilor şi reacţiilor }\end{array}$ \\
\hline Comportamentală & $\begin{array}{l}\text { Comportamentele } \\
\text { observabile ale clientului } \\
\text { (Bandura, 1977) }\end{array}$ & $\begin{array}{l}\text { Diferite tipuri de întăriri; } \\
\text { pedeapsa }\end{array}$ & $\begin{array}{l}\text { Înţelegerea antecedentelor şi } \\
\text { consecinţelor comportamentului; } \\
\text { schimbarea comportamentului; } \\
\text { pattern-urilor de acţiune }\end{array}$ \\
\hline Centrată pe persoană & $\begin{array}{l}\text { Înţelegerea de sine fără } \\
\text { intervenţia directă a } \\
\text { practicianului } \\
\text { (Rogers \& Wood, 1974) }\end{array}$ & $\begin{array}{l}\text { Relaţie terapeutică bazată pe } \\
\text { încredere şi empatie }\end{array}$ & $\begin{array}{l}\text { Nou mod de a gândi care } \\
\text { generează emoţii pozitive şi } \\
\text { relaţii eficiente }\end{array}$ \\
\hline Cognitiv-terapeutică & $\begin{array}{l}\text { Gândurile conştiente ale } \\
\text { clientului } \\
\text { (Beck, 1995) }\end{array}$ & $\begin{array}{l}\text { Identificarea gândurilor iraţionale } \\
\text { şi gândirea distorsionată }\end{array}$ & $\begin{array}{l}\text { Dezvoltarea personală, } \\
\text { schimbarea }\end{array}$ \\
\hline Orientată pe sistem & $\begin{array}{l}\text { Influenţe individuale, de } \\
\text { grup şi organizaţionale } \\
\text { asupra comportamentului } \\
\text { clientului } \\
\text { (Day \& O'Connor, 2003; } \\
\text { Peltier, 2001) }\end{array}$ & $\begin{array}{l}\text { Date şi analiza interacţiunilor } \\
\text { clientului cu alte persoane; } \\
\text { comportamentele de rol; grup, } \\
\text { relaţii cu grupul; intervenţie } \\
\text { directă în cadrul organizaţiei }\end{array}$ & $\begin{array}{l}\text { Eficienţă crescută la nivel } \\
\text { individual în muncă, la nivel de } \\
\text { grup şi organizaţional }\end{array}$ \\
\hline
\end{tabular}

Modelele fundamentate pe teoria modificărilor cognitiv-comportamentale valorifică modele clinice consacrate şi le adaptează în intervenţia organizaţională. Majoritatea acestor modele au sustenabilitate empirică şi pot fi relativ uşor adaptate la nevoile şi particularităţile programelor de coaching. O astfel de adaptare este oportună de vreme ce, deşi domeniile şi contextul terapiei şi ale coaching-ului sunt diferite, modificările comportamentale constituie componente esenţiale de intervenţie la care fac apel atât terapeuţii, cât şi practicienii coaching-ului (Rotenberg, 2000). Aşadar, coaching-ul de pe poziţiile modelelor cognitiv-comportamentale poate fi o secvenţă de intervenţie - asupra sănătăţii şi bolii în organizaţie - care influenţează eficienţa unei organizaţii (David, 2007). Dintre abordările de orientare clinică, terapia raţional-emotiv-comportamentală (REBT) a fost adaptată cu succes la coachingul organizaţional. În practica curentă, coaching-ul care încorporează principii şi tehnici REBT este numit coaching raţionalemotiv-comportamental (Kirby, 1993). Nu este vorba de o simplă etichetă, ci de o modalitate de a sugera specificitatea programului în raport cu alte forme de coaching, precum şi în 
relaţie cu paradigma teoretică din care a fost extras şi dezvoltat (Opre, 2007).

Modelele şi cadrele teoretice globale, generale, aplicabile în orice formă de coaching sunt destul de puţine. Mai degrabă, s-au conturat modele specifice care orientează intervenţia pe probleme ţintă, cum este cel care evidenţiază cele patru roluri diferite în coaching (Witherspoon \& White, 1996), sau cel care accentuează utilitatea feedback-ului (Waclawski \& Church, 1999). Modelele specifice au în comun descrierea stadiilor procesului de coaching, tehnicile şi instrumentele de evaluare: (Brotman, Liberi \& Wasylyshyn, 1998; Harris, 1999; Kilburg, 1996; Witherspoon \& White, 1996). O limită a acestor modele este aceea că fiecare se axează pe dimensiuni şi componentele amintite şi nu pe proces ca întreg.

Modelul contextual este mai degrabă un meta-model ce constituie un cadru pentru un coaching interdisciplinar, bazat pe date care subliniază natura complementară a abordărilor empirice şi constructivist-narative (Stober \& Grant, 2006). Este un model care subsumează mai multe principii care fundamentează procesul de coaching:

(1). rezultatul sau scopul explicit stabilit de practician şi client prin cooperare;

(2). explicaţia pentru modul în care coaching-ul este adecvat nevoilor clientului şi situaţiei;

(3). procedura sau setul de paşi consistent cu modelul pe care se fundamentează procesul; (4). relaţia între practician şi client;

5). alianţa practician-client în care rolul explicit al practicianului este de a dezvolta clientul, de a-i optimiza performanţa şi abilităţile, prin declanşarea şi facilitarea schimbării;

(6). abilitatea clientului şi disponibilitatea lui pentru schimbare;

(7). abilitatea practicianului şi pregătirea sa pentru a realiza schimbarea în principal, abilitatea personală de a recunoaşte şi de a gestiona probleme deseori foarte personale care pot apărea într-o intervenţie de coaching (Stober \& Grant, 2006).

Modelul contextual, cu principiile de eficienţă propuse, poate acţiona ca şi un cadru cuprinzător în care diferite abordări pot fi integrate.

O viziune mai complexă este adusă de sintagma şi binecunoscuta abordare de tip cercetător-practician (Kleinberg, 2001). Modelul integrativ de coaching care evidenţiază interacţiunea individ-organizaţie, precum şi influenţele intrapsihice, interpersonale şi organizaţionale asupra intervenţiei de coaching aduce contribuţii valoroase la dezvoltarea sa (Orenstein, 2000).

În ciuda varietăţii modelelor teoretice existente în literatură, elementul comun al acestora este dat de înţelegerea coaching-ului ca proces de dezvoltare prin responsabilitate şi angajament al celor doi actori implicaţi (client şi practician).

\section{Eficienţa coaching-ului}

Dincolo de construirea de modele care să orienteze practica, studiile s-au focalizat pe evaluarea eficienţei intervenţiilor de coaching. Astfel de studii sunt puţin numeroase şi se axează, în principal, pe EC ca forma cea mai vizibilă în practică. Până în prezent, cercetările au indicat efecte pozitive ale intervenţiei asupra clienţilor (Passmore, 2007), deşi există o mare diversitate în ceea ce priveşte atât factorii investigaţi, cât şi instrumentele de măsurare. Rezultatele eficienţei coaching-ului pot fi încadrate în trei categorii: (a) modificări ale comportamentului de conducere; (b) percepţia clientului privind procesul de coaching; (c) măsura obiectivă a performanţei (vezi tabelul 3). Prin definiţie, ţinta coachingului este învăţarea şi modificarea comportamentală, prin urmare, nu este deloc surprinzător că majoritatea studiilor se axează pe această dimensiune. Mai mult, studiile identifică o relaţie pozitivă între coaching şi modificarea comportamentală, în termeni de stabilire a scopurilor, angajamentului în muncă, productivitatea, dialogul şi comunicarea, gestionarea subalternilor (Kombarakaran, Yang, Baker, \& Fernandes, 2008; Levenson, 2009).

Ca rezultate distale ale EC sunt echilibrul muncă-viaţă şi starea de bine, reducerea stresului (Gyllensten \& Palmer, 2005) şi o mai bună aliniere a scopurilor personale la scopurile şi misiunea organizaţională. Aceste rezultate se bazează pe percepţia clienţilor privind impactul coaching-ului sau pe dorinţa de a repeta experienţa de coaching, dar nu demonstrează, în mod obiectiv şi eficacitatea intervenţiei. În unele studii, alături de percepţia rezultatelor de către clienţi, s-au raportat evaluări ale supervizorilor, subalternilor sau ale persoanelor din departamentul de resurse umane, oferind o perspectivă mai completă asupra succesului intervenţiei (Diedrich, 1996; Smither, London, Flautt, Vargas, \& Kucine, 2003, Joo, 2005, McGovern, Lindemann, Vergara, Murphy, Barker \& Warrenfeltz, 2001). 
În ceea ce priveşte performanţa care poate fi definită în mod obiectiv, sunt menţionate doar câteva studii (Olivero, Bane, \& Kopelman, 1997; Bowles, Cunningham, De La Rosa, \& Picano, 2007). Acestea demonstrează că EC poate influenţa performanţa persoanei cu funcţii de conducere, dar este dificil să se izoleze efectul coaching-ului de impactul altor factori.

McGovern et al. (2001) diferenţiază rezultatele coaching-ului în tangibile (creşterea productivităţii) şi intangibile (munca în echipă, satisfacţia profesională). Rezultatele tangibile au fost exprimate în ROI (return of investment), care estimează procentul de profit faţă suma investită.

Puţine cercetări raportează rezultatele obţinute la nivelul grupului de intervenţie, în raport cu grupul de control (Smither et al., 2003). Însă, o astfel de procedură ar fi deosebit de utilă în ilustrarea efectelor procesului de coaching şi departajarea acestora de alte surse de învăţare.

Tabelul 3. Sinteza rezultatelor intervenţiei EC

\begin{tabular}{|c|c|c|c|}
\hline Autor, an & Tip studiu & Participanţi & Rezultate ale intervenţiei EC \\
\hline Diedrich, 1996 & $\begin{array}{l}\text { studiu de caz, } \\
\text { longitudinal }\end{array}$ & 1 leader & comportament de conducere optimizat \\
\hline Foster \& Lendl, 1996 & studiu de caz & 4 & $\begin{array}{l}\text { schimbarea comportamentului; } \\
\text { scăderea anxietăţii faţă de interviul de } \\
\text { angajare; satisfacţie }\end{array}$ \\
\hline $\begin{array}{l}\text { Olivero, Bane \& } \\
\text { Kopelman, } 1997\end{array}$ & studiu comparativ & 31 manageri & $\begin{array}{l}\text { beneficii la nivel de cunoştinţe, } \\
\text { comportament; performanţă ridicată în } \\
\text { urma intervenţiei de coaching la } 88 \text { \% } \\
\text { dintre participanţi }\end{array}$ \\
\hline Hall, Otazo et al., 1999 & studiu exploratoriu & $\begin{array}{l}75 \text { de persoane cu funcţii } \\
\text { de conducere şi } 15 \\
\text { practicieni }\end{array}$ & $\begin{array}{l}\text { eficienţă în muncă, o mai mare } \\
\text { flexibilitate şi adaptabilitate }\end{array}$ \\
\hline $\begin{array}{l}\text { Smither, London et al., } \\
2003\end{array}$ & studiu cvasiexperimental & 400 manageri & relaţionare mai bună \\
\hline Dagley, 2006 & studiu exploratoriu & $\begin{array}{l}17 \text { specialişti în resurse } \\
\text { umane }\end{array}$ & $\begin{array}{l}\text { dezvoltarea comportamentului de } \\
\text { conducere }\end{array}$ \\
\hline $\begin{array}{l}\text { Evers, Brouwers \& } \\
\text { Tomic, } 2006\end{array}$ & studiu cvasiexperimental & 2 grupuri de manageri & $\begin{array}{l}\text { creşterea autoeficacităţii, stabilirea de } \\
\text { scopuri precise, relaţii echilibrate, } \\
\text { echilibru muncă-viaţă }\end{array}$ \\
\hline $\begin{array}{l}\text { Jones, Rafferty \& Griffin, } \\
2006\end{array}$ & $\begin{array}{l}\text { studiu exploratoriu bazat } \\
\text { pe design cu măsurători } \\
\text { repetate }\end{array}$ & 11 manageri & creştere a flexibilităţii manageriale \\
\hline Libri, \& Kemp, 2006 & $\begin{array}{l}\text { experiment cu un singur } \\
\text { subiect }\end{array}$ & $\begin{array}{l}1 \text { participant (deţine funcţie } \\
\text { de conducere) }\end{array}$ & creşterea performanţei şi autoeficacităţii \\
\hline $\begin{array}{l}\text { Bowles, Cunningham et } \\
\text { al., } 2007\end{array}$ & $\begin{array}{l}\text { studiu exploratoriu } \\
\text { longitudinal }\end{array}$ & $\begin{array}{l}30 \text { manageri nivel mediu şi } \\
29 \text { persoane cu funcţii de } \\
\text { conducere }\end{array}$ & $\begin{array}{l}\text { competenţe în recrutarea subordonaţilor } \\
\text { şi stabilirea mai precisă a scopurilor }\end{array}$ \\
\hline Burke \& Linley, 2007 & studiu experimental & 26 participanţi & atingerea scopurilor \\
\hline Feggetter, 2007 & studiu exploratoriu & $\begin{array}{l}10 \text { persoane din ministerul } \\
\text { apărării }\end{array}$ & $\begin{array}{l}\text { abilităţile de conducere, percepţia } \\
\text { progresului personal, beneficii financiare }\end{array}$ \\
\hline $\begin{array}{l}\text { Kombarakaran, Yang et } \\
\text { al., } 2008\end{array}$ & studiu comparativ & $\begin{array}{l}114 \text { persoane cu funcţii de } \\
\text { conducere } \\
42 \text { practicieni }\end{array}$ & $\begin{array}{l}\text { dezvoltarea conducerii, relaţii eficiente } \\
\text { cu managerii, stabilirea scopurilor şi } \\
\text { prioritizare, angajament şi productivitate, } \\
\text { dialog şi comunicare. }\end{array}$ \\
\hline Hauser, 2009 & studiu de caz & 1 participant & $\begin{array}{l}\text { echilibru muncă-viaţă, valorificarea } \\
\text { oportunităţilor de învăţare }\end{array}$ \\
\hline Perkins, 2009 & studiu exploratoriu & 21 participanţi & $\begin{array}{l}\text { modificări pozitive ale comportamentul } \\
\text { de conducere }\end{array}$ \\
\hline Levenson, 2009 & studiu exploratoriu & 12 perechi client-practician & profit economic \\
\hline
\end{tabular}


Jumătate dintre articolele cuprinse în sinteza de faţă au un caracter descriptiv şi raportează succesiunea etapelor în intervenţia de coaching, date demografice privind practicienii şi clientiii, unele rezultate, dar nu explică legătura cauzală între factorii care asigură succesul intervenţiei (Diedrich, 1996; Kiel et al., 1996; Peterson, 1996; Tobias, 1996; Hauser, 2009). În ciuda ubicuităţii EC în organizaţii, studiile descriptive subliniază lipsa de uniformitate a instrumentelor de evaluare, abordărilor, scopurilor şi metodelor de măsurare a rezultatelor. Datele sunt obţinute prin studii de caz, interviuri şi observaţie. Majoritatea cercetărilor utilizează un număr restrâns de participanţi în încercarea de a contura cadre şi relaţii între intervenţia asupra clientului şi rezultatele obţinute. Metodologia utilizată este preponderent calitativă - analiza fenomenologică, analiza narativă şi analiza de conţinut care, deşi aduc nuanţări valoroase, nu identifică predictorii succesului.

O altă categorie de studii (o treime) este reprezentată de cele care lansează ipoteze şi conturează modele, dar fără a le testa validitatea (Wasylyshyn, 2003). Studiile explicative centrate pe găsirea relaţiei de cauzalitate între intervenţia de coaching şi rezultate sunt puţin numeroase $(10 \%)$ şi au la bază design cvasi-experimental (Smither et al., 2003; Evers, Brouwers, \& Tomic, 2006), rareori experimental (Libri \& Kemp, 2006; Burke \& Linley, 2007). Numărul redus de studii experimentale se datorează dificultăţii de izolare a factorilor şi variabilelor care pot interveni. Totuşi, cele câteva articole cu date cantitative subliniază un efect semnificativ al intervenţiei pozitive de EC (vezi tabelul 3). Însă, proporţia redusă de date cantitative face imposibilă realizarea de meta-analize care să pună în evidenţă efectele anumitor variabile asupra rezultatelor. Un alt neajuns este numărul redus de cercetări de tip longitudinal identificate (Diedrich, 1996; Blattner, 2005; Evers et al., 2006). Deoarece coaching-ul este un proces de schimbare umană, este imperativ a fi înţeles şi observat longitudinal, prin cercetare care să explice procesul de schimbare în timp.

\section{Mecanismele de schimbare în coaching}

Dincolo de a demonstra eficienţa intervenţiei de coaching, studiile au căutat identificarea variabilelor care determină şi potenţează schimbarea. Un factor important s-a dovedit a fi tocmai motivaţia pentru schimbare şi pentru învăţare care influenţează angajarea într-un coaching eficient (Wasylyshyn, 2003). Feedback-ul este considerat nu doar o componentă a procesului, ci şi un factor cheie pentru schimbare (Diedrich, 1996; Kampa-Kokesch \& Anderson, 2001; Witherspoon \& White, 1996; Joo, 2005; Gregory et al., 2008). Un procent semnificativ (84\%) dintre clienţi percep relaţia practicianclient ca factor major pentru succesul coaching-ului (McGovern et al., 2001). Chiar dacă o astfel de relaţie influenţează succesul intervenţiei, nu există studii care să demonstreze legătura dintre diada practicianclient şi rezultat (Kampa \& White, 2002; Kampa-Kokesch \& Anderson, 2001; Kilburg, 2001; Lowman, 2005).

Alte cercetări sugerează că anumite caracteristici ale practicianului (vârstă, pregătire, experienţă profesională) pot influenţa credibilitatea percepută a practicianului şi deschiderea clientului la experienţa legată de coaching. Totuşi, această asociere nu a fost demonstrată empiric decât de puţine studii (Kampa \& White, 2002). Cercetările demonstrează relevanţa pregătirii psihologice a practicienilor coaching-ului. Psihologii apar ca fiind cei mai calificaţi pentru coaching datorită cunoştinţelor privind teorii ale dezvoltării umane, înţelegerea personalităţii, evaluarea performanţei şi abilităţilor lor în a construi o relaţie de încredere şi confidenţială cu clientul (Brotman et al., 1998; Kilburg, 1996; Sperry, 1996). Alţi autori au subliniat importanţa înţelegerii contextului de business, a principiilor de management, a politicilor organizaţionale (Diedrich \& Kilburg, 2001; Saporito, 1996; Tobias, 1996). Coaching-ul eficient integrează dinamic abordări ale psihologiei individului şi nevoile organizaţiei, atât la nivel individual, cât şi sistemic, luând în considerare contextul intervenţiei (Lowman, 2005). O înţelegere a culturii corporatiste în care intervenţia are loc este esenţială. De asemenea, sunt necesare studii care să demonstreze specificul programelor formare şi acreditare a specialiştilor în coaching.

Numărul limitat de cercetări ştiinţifice riguroase se datorează mai multor factori: noutatea domeniului pentru psihologie, aspecte de confidenţialitate ale participanţilor, lipsa unor teorii unanim acceptate care să ghideze practica. Totodată, nu există o metodologie specifică evaluării eficienţei coaching-ului, ceea ce face dificilă 
compararea rezultatelor. Dată fiind dificultatea realizării unor studii experimentale controlate în situaţ̧ii de coaching, cercetarea viitoare trebuie să recurgă la alte tipuri de design.

\section{Consideraţii finale}

Sinteza literaturii de specialitate subliniază lipsa unei coerenţe teoretice în fundamentarea coaching-ului, precum şi proliferarea unei multitudini de modele şi metode în coaching. În ciuda acestei inconsistenţe teoretice există un consens privind beneficiile intervenţiei de coaching, atât la nivel personal, cât şi la nivel organizaţional. Definirea variată a termenului de coaching şi a formelor sale, precum şi abordările teoretice foarte diferite care ghidează intervenţiile pot constitui obstacole în cercetare şi în generalizarea rezultatelor.

O mare parte a cercetărilor sunt de natură fenomenologică, utilizează un număr mic de participanţi în încercarea de a dezvolta pattern-uri de relaţii între experienţa de coaching a clientului şi rezultatele obţinute. Majoritatea cercetărilor sunt studii de caz şi testări ale unor cadre metodologice şi doar unele din acestea se constituie în abordări sistemice care să implice simultan agenţii procesului. Referitor la măsurare, nu se recurge la instrumente psihometrice, ci se bazează, în general, pe un material narativ şi instrumente de evaluare idiografice (Laske, 2004; Orenstein, 2006). Acest lucru face dificilă compararea rezultatelor obţinute în mai multe studii de caz, ca şi încercarea de a replica studiile.

Dincolo de datele calitative şi cantitative privind eficienţa în coaching, o parte din cercetarea în domeniu este centrată pe conţinut, vizează procesul şi modul cum se relaţionează cu teoriile existente în diferite discipline: psihologie, managementul bazat pe calitate, învăţarea adulţilor, dezvoltarea individuală şi organizaţională, consultanţa în afaceri şi psihologia clinică (Bennett, 2006).

Spre deosebire de alte tipuri de intervenţie, coaching-ul nu se pretează la a fi studiat în cadrul artificial de laborator. Fundamentarea coaching-ului pe cercetarea empirică este absolut necesară pentru a asigura dezvoltarea sa. Cercetările în domeniu au o importanţă deosebită pentru fundamentarea şi susţinerea practicii, pentru formarea practicienilor şi pentru dezvoltarea unor teorii specifice. Stadiul actual al cercetării din domeniul coaching-ului pune în evidenţă nevoia de integrare teoretică şi empirică, ca şi nevoia pentru mai multe cercetări de coaching orientate pe proces şi pe finalităţi.

Este de dorit ca cercetările viitoare să aducă o clarificare pe următoarele componente: 1). practicianul: caracteristici, competenţe; 2). clientul: caracteristici, disponibilitatea sa pentru intervenţia de coaching; 3 . relaţia practician-client: compatibilitate, calităţile relaţiei, tipuri de relaţie. 4). procesul: etape, tipuri de intervenţie, scopuri; 5). rezultatele: tipul, sustenabilitatea, impactul; 6). teorii ale coaching-ului: practica şi formarea în coaching (Bennett, 2006). Un alt scop central al cercetării ar trebui să fie conturarea unei metodologii validate empiric şi particularizată pe principalele forme de coaching.

Dincolo de limitele cercetării din domeniul coaching-ului, sinteza de faţă pune în evidenţă rezultate valoroase care constituie premise pentru noi direcţii de studiu. De asemenea, rezultatele identificate indică un interes constant pentru dezvoltarea şi individualizarea coaching-ului, ca profesie de sine stătătoare.

\section{Bibliografie}

Auerbach, J. E. (2001). Personal and executive coaching: The complete guide for mental health professionals. Ventura, CA: Executive College Press.

Bandura, A. (1977). Social Learning Theory. New York: General Learning Press.

Banning, K. L. (1997). Now, coach? Across the Board, 34, 28-32.

Barner, R., \& J. Higgins (2007). Understanding implicit models that guide the coaching process. Journal of Management Development, 26(2), 148-158.

Beck, J. (1995). Cognitive therapy: Basics and beyond. New York: Guilford Press.

Bennett, J.L. (2006). An agenda for coachingrelated research: $A$ challenge for researchers. Consulting Psychology Journal: Practice and Research, 58(4), 240-249.

Berry, R. M. (2006). A comparison of face-to-face and distance coaching practices: The role of the working alliance in problem resolution. Dissertation Abstracts International: Section B., 67(6-B), 3439.

Blattner, J. (2005). Coaching: The successful adventure of a downwardly mobile 
executive. Consulting Psychology Journal: Practice and Research, 57(1), 3-13.

Blumer, H. (1986). Symbolic Interactionism: Perspective and Method. University of California Press, Berkeley, CA.

Bowles, S.V., Cunningham, C.J.L., De La Rosa, G.M., \& Picano, J.J. (2007). Coaching Leaders in Middle and Executive Management: Goals, Performance, Buy-in. Leadership and Organization Development Journal 28(5), 388-408.

Brennan, D., \& Prior, D. M. (2005). The future of coaching as a profession: The next five years 2005-2010. Lexington, KY: International Coach Federation.

Brotman, L. E., Liberi, W. P., \& Wasylyshyn, K. M. (1998). Executive coaching: The need for standards of competence. Consulting Psychology Journal: Practice \& Research, 50(1), 40-46.

Burke, D., \& Linley, P. A. (2007). Enhancing goal self-concordance through coaching. International Coaching Psychology Review, 2(1), 62-69.

Cox, E., Bachkirova, T., \& Clutterbuk, D.A. (2009). The Complete Handbook of Coaching. Sage Publications.

Dagley. G. (2006). Human resources professionals' perceptions of executive coaching: Efficacy, benefits and return on investment. International Coaching Psychology Review, 1(2), 34-45.

David, D. (2007). O perspectivă cognitivcomportamentală asupra psihologiei muncii şi organizaţiilor. Sistem de coaching CBT. În D. DiMattia (editor). Coaching cognitiv-comportamental în organizaţii; Antrenamentul eficienţei raţionale (9-27). Cluj-Napoca: Editura ASCR.

Day, D. V., \& O'Connor, P. M. (2003). Leadership development: Understanding the process. In S. Murphy, \& R. Riggio (Eds.), The future of leadership development, (11-28). Mahweh, NJ: Lawrence Erlbaum.

De Meuse, K.P., Dai, G., \& Lee, R.J.(2009). Evaluating the effectiveness of executive coaching: beyond ROI? Coaching: An International Journal of Theory, Research and Practice, 2(2),117-134.

Diedrich, R. C. (1996). An interactive approach to executive coaching. Consulting Psychology Journal: Practice \& Research, 48(2), 6166.

Diedrich, R., \& Kilburg, R. (2001). Further consideration of executive coaching as an emerging competency. Consulting
Psychology Journal: Practice and Research 53(4), 203-204.

Eggers, J., \& Clark, D. (2000). Executive coaching that wins. Ivey Business Journal, 65(1), 6670.

Eitington, J. (1997). Winning manager: Leadership skills for greater innovation, quality and employee commitment. Houston, TX: Gulf Publishing.p. 208

Ennis, S., Goodman, R., Otto, J., \& Stern, L. R. (2008). The executive coaching handbook. Principles and Guidelines for a Successful Coaching Partnership. Wellesley, MA: The Executive Coaching Forum.

Evers, W. J. G., Brouwers, A., \& Tomic, W. (2006). A Quasi-experimental Study on Management Coaching Effectiveness. Consulting Psychology Journal: Practice \& Research, 58(3), 174-182.

Fairley, S. \& Stout, C. (2004). Getting Started in Personal and Executive Coaching, New York: John Wiley \& Sons, Inc.

Feggetter, A.W.J. (2007). A preliminary evaluation of executive coaching: Does executive coaching work for candidates on a high potential development scheme? International Coaching Psychology Review, 2(2), 129 - 142.

Feldman, D. C. \& Lankau, M. J. (2005). Executive Coaching: A Review and Agenda for Future Research. Journal of Management, 31(6); 829-848.

Filipczak, B. (1998). The executive coach. Helper or healer. Training, 35(3), 30-36.

Ford, J.D. (1999). Organizational change and shifting conversations. Journal of Organizational Change Management, 12(6), 480-500.

Foster, S., \& Lendl, J. (1996). Eye movement desensitization and reprocessing: Four case studies of a new tool for executive coaching and restoring employee performance after setbacks, Consulting Psychology Journal: Practice and Research, 48(3), 155-161.

Gale, S. \& Lindner, H. (2007). The Health Coaching Australia (HCA) Model of Health Coaching for Chronic Condition Self-management (CCSM). www.healthcoachingaustralia.com

Garman, A. N., Whiston, D. L., \& Zlatoper, K.W. (2000). Media perceptions of executive coaching and the formal preparation of coaches. Consulting Psychology Journal: Practice and Research, 52(3), 201-205.

Grant, A. M. (2006). A personal perspective on professional coaching and the 
development of Coaching Psychology. International Coaching Psychology Review, 1(1), 12-22.

Grant, A. M. (2007). A model of goal striving and mental health for coaching populations. International Coaching Psychology Review, 2(3), 248-262.

Grant, A. M. (2008). Workplace, Executive and Life Coaching: An Annotated Bibliography from the Behavioural Science Literature. Coaching Psychology Unit, University of Sydney, Australia.

Grant, A.M., \& Zackon, R. (2004). Executive, Workplace and Life Coaching: Findings from a Large-Scale Survey of International Coach Federation Members. International Journal of Evidence Based Coaching and Mentoring, 2(2), 1-15.

Gregory, J.B., Levy, P.E., \& Jeffers, M. (2008). Development of a model of the feedback process within executive coaching. Consulting Psychology Journal: Practice and Research, 60(1), 42-56.

Gyllensten K, Palmer S (2005). Can coaching reduce work-place stress? The Coaching Psychologist, 1(July), 15-17.

Hall, D. T., Otazo, K. L., \& Hollenbeck, G. P. (1999). Behind closed doors: What really happens in executive coaching. Organizational Dynamics, 27, 39-53.

Harris, M. (1999). Practice network: Look, it's an I-O psychologist... No, it's a trainer . . . No, it's an executive coach! The Industrial-Organizational Psychologist, 36(3), 38-42.

Hauser, L. (2009). Evidence-based coaching. A case study. OD Practitioner, 41(1), 1-7.

Higgins, M. C., \& Kram, K. E. (2001). Reconceptualizing mentoring at work: A developmental network perspective. Academy of Management Review, 26(2), 264-288.

Hodgetts, W. H. (2002).Using executive coaching in organizations: What can go wrong (and how to prevent it). In C. Fitzgerald \& J. G. Berger (Eds.), Executive coaching: Practices and perspectives (pp. 203223). Palo Alto, CA: Davis-Black.

Irwin, J. D., \& Morrow, D. (2005). Health promotion theory in practice: An analysis of Co-Active coaching. International Journal of Evidence Based Coaching and Mentoring, 3(1), 2938.

Jarvis, J. (2004). Coaching and buying coaching services?. London: CIPD.

Jones, R. A., Rafferty, A. E., \& Griffin, M. A. (2006). The executive coaching trend: Towards more flexible executives. Leadership and Organisational Development Journal, 27(7), 584-596

Joo, B. (2005). A Conceptual Framework From an Integrative Review of Practice and Research. Human Resource Development Review, 4(4), 462-488.

Judge, W.Q., \& Cowell, J. (1997). The brave new world of executive coaching. Business Horizons, 40(4), 71-77.

Kampa, S., \& White, R. P. (2002). The effectiveness of executive coaching: What we know \& what we still need to know. In R. L. Lowman (Ed.), Handbook of organizational consulting psychology (pp. 139-158). San Francisco: Jossey-Bass.

Kampa-Kokesch, S., \& Anderson, M. Z. (2001). Executive coaching: A comprehensive review of the literature. Consulting Psychology Journal: Practice and Research, 53(4), 205-228.

Kiel, R., Rimmer, E., Williams, K., \& Doyle, M. (1996). Coaching at the top. Consulting Psychology Journal: Practice and Research, 48(2), 67-77.

Kilburg, R. R. (1996). Toward a conceptual understanding and definition of executive coaching. Consulting Psychology Journal: Practice and Research, 48(2), 134-144.

Kilburg, R.R. (2001). Facilitating intervention adherence in executive coaching: A model and methods. Consulting Psychology Journal: Practice \& Research, 53(4), 251267.

Kilburg, R.R. (2004). Trudging Toward Dodoville: Conceptual Approaches and Case Studies in Executive Coaching. Consulting Psychology Journal: Practice and Research, 56(4), 203-213.

Kirby, P. (1993). RET counseling: Application in management and executive development. Journal of Rational-Emotive \& Cognitive Behavior Therapy, 11, 7-18.

Kleinberg, J. A. (2001). A scholar-practitioner model or executive coaching: Applying theory and application within the emergent field of executive coaching. DAl, 61(12), 4853A.

Kleinberg, J. A. (2003). A scholar-practitioner model: Constructing a holistic theoretical system to organize approaches to executive coaching. In I. F. Stein \& L. A. Belsten (Eds.), Proceedings of the First International Coach Federation Coaching Research Symposium (pp. 1-19). Mooresville, NC: Paw Print Press.

Kombarakaran, F.A., Yang, J.A., Baker, M.N., \& Fernandes, P.B. (2008). Executive 
coaching: It works! Consulting Psychology Journal: Practice and Research, 60(1), 7890.

Kutzhanova, N., Lyons, T.S, \& Lichtenstein, G.A., (2009). Skill-Based Development of Entrepreneurs and the Role of Personal and Peer Group Coaching in Enterprise Development. Economic Development Quarterly, 23, 193-210

Laske, O. (2004). Can Evidence Based Coaching Increase ROI? International Journal of Evidence Based Coaching and Mentoring, 2(2), 41-53.

Latham, G. P. (2007). Theory and research on coaching practices. Australian Psychologist, 42(4), 268-270.

Lawton-Smith, C., \& Cox, E. (2007). Coaching: Is it just a new name for training? International Journal of Evidence Based Coaching and Mentoring (Summer), 1-9.

Levenson, A. (2009). Measuring and maximizing the business impact of executive coaching. Consulting Psychology Journal: Practice and Research, 61(2), 103-121.

Libri, E. \& Kemp, T.J. (2006). Assessing a Cognitive Behavioural Executive Coaching Program. International Coaching Psychology Review, 1(2), 9-20.

Lowman, R.L., (2005). Executive Coaching: The Road to Dodoville Needs Paving With More Than Good Assumptions. Consulting Psychology Journal: Practice and Research, 57(1), 90-96.

McCauley, C.D., \& Hezlett, S.A. (2001). Individual development in theworkplace. In N.Anderson, D. Ones, H. K. Sinangil,\&C. Viswesvaran (Eds.), Handbook of industrial, work, and organizational psychology (Vol. 2, 313-335). London: Sage

McGovern, J., Lindemann, M., Vergara, M., Murphy, S., Barker, L. \& Warrenfeltz, R. (2001). Maximizing the Impact of Executive Coaching: Behavioral Change, Organizational Outcomes, and Return on Investment. The Manchester Review, 6(1), 1-9.

McKelley, R. A. \& A. B. Rochlen (2007). The Practice of Coaching: Exploring Alternatives to Therapy for CounselingResistant Men. Psychology of Men \& Masculinity, 8(1), 53-65

Nowack, K. M., \& Wimer, S. (1997). Coaching for human performance. Training and Development Journal, 51(10), 28-32.

Olivero, G., Bane, K. D., \& Kopelman, R. E. (1997). Executive training as a transfer of training tool: Effects on productivity in a public agency. Public Personnel Management, 26, 461-469.

Opre, A. (2007). Coaching managerial. În D. DiMattia (editor). Coaching cognitivcomportamental in organizaţii; Antrenamentul eficienţei raţionale (29-50). Cluj-Napoca: Editura ASCR.

Orenstein, R. L. (2000). Executive coaching: An integrative model. $D A I-B$ 61/04, 2257

Orenstein, R.L. (2006). Measuring executive coaching efficacy? The answer was right here all the time. Consulting Psychology Journal: Practice and Research, 58(2), 106-116.

Palmer, S., Tubbs, I. \& Whybrow, W. (2003). Health coaching to facilitate the promotion of healthy behaviour and achievement of health-related goals. International Journal of Health Promotion and Education, 41(3), 91-93.

Passmore, J. (2007). An Integrative Model for Executive Coaching. Consulting Psychology Journal: Practice and Research, 59(1), 68-78.

Peltier, B. (2001). The psychology of executive coaching: Theory and application. Ann Arbor, MI: Brunner-Routledge Taylor and Francis Group.

Perkins, R.D. (2009). How executive coaching can change leader behavior and improve meeting effectiveness: An exploratory study. Consulting Psychology Journal: Practice and Research, 61(4), 298-318.

Peterson, D. B. (1996). Executive coaching at work: The art of one-on-one change. Consulting Psychology Journal: Practice and Research, 48(2), 78-86.

Rock, A. D. \& Garavan, T. N. (2006). Reconceptualizing developmental relationships. Human Resource Development Review, 5(3), 330-354.

Rogers, C., \& Wood, J. (1974). Client-centered theory: Carl Rogers. In A. Burton (Ed.), Operational Theories of personality (211258). New York: Brunner/Mazel.

Rotenberg, C. T. (2000). Psychodynamic psychotherapy and executive coaching Overlapping paradigms. Journal of the American Academy of Psychoanalysis, 28, 653-663.

Saporito, T. J. (1996). Business-linked executive development: Coaching senior executives. Consulting Psychology Journal: Practice and Research, 48(2), 96-103. 
Sherman,S., \& Freas, A. (2004). The Wild West of executive coaching. Harvard Business Review, 82(11), 82-90.

Smither, J.W., London,M., Flautt, R., Vargas, Y., \& Kucine, I. (2003). Can working with an executive coach improve multisource feedback ratings over time? A quasiexperimental field study. Personnel Psychology, 56(1), 23-44.

Sperry, L. (1993). Working with executives: Consulting, counseling, and coaching. Individual Psychology, 49, 257-266.

Sperry, L. (1996). Corporate therapy and consulting. New York: Brunner/Mazel.

Sperry, L. (2004). Executive Coaching. The Essential Guide for Mental Health Professionals. Brunner Routledge Taylor \& Francis Group, New York and Hove

Stern, L. S. (2004). Executive coaching: A working definition. Consulting Psychology Journal: Practice and Research, 56(3), 1-14.

Stober, D. \& Grant, A. (2006). Evidence-based coaching handbook. New York: J Wiley and Sons.

Tobias, L. (1996). Coaching executives. Consulting Psychology Journal: Practice and Research, 48(2), 87-95.
Underhill, B.O., McAnally, K. \& Koriatt, J.J. (2007). Executive Coaching for Results. The Definitive Guide to Developing Organizational Leaders. Berrett-Koehler Publishers, Inc.

Waclawski, J., \& Church, A. H. (1999). Four easy steps to performance coaching. Performance in Practice, 4-5.

Wasylyshyn, K.M. (2003). Executive coaching: An outcome study. Consulting Psychology Journal: Practice and Research, 55(2), 94106.

Wilkins, B. M. (2000). A grounded theory study of personal coaching. DAI, A61(5): 1713.

Williams \& Davis (2002). Therapist as life coach: Transforming your practice. New York: Norton.

Witherspoon, R., \& White, R. P. (1996). Executive coaching: A continuum of roles. Consulting Psychology Journal: Practice \& Research, 48 (2), 124-133.

Young, A.M., \& Perrewe, P.L. (2000). What did you expect? An examination of career-related support and social support among mentors and protégés. Journal of Management, 26, 611-632. 